\title{
Caffeic Acid on Metabolic Syndrome: A Review
}

\author{
Nellysha Namela Muhammad Abdul Kadar ${ }^{1,2}$, Fairus Ahmad ${ }^{1}$, , Seong Lin Teoh ${ }^{1}(\mathbb{D}$ \\ and Mohamad Fairuz Yahaya ${ }^{1, *}$ \\ 1 Department of Anatomy, Faculty of Medicine, Universiti Kebangsaan Malaysia Medical Centre, Cheras, \\ Kuala Lumpur 56000, Malaysia; nellysha.namela@ums.edu.my (N.N.M.A.K.); \\ fairusahmad@ukm.edu.my (F.A.); teohseonglin@ukm.edu.my (S.L.T.) \\ 2 Department of Biomedical Sciences and Therapeutics, Faculty of Medicine and Health Sciences, \\ Universiti Malaysia Sabah, Kota Kinabalu 88400, Malaysia \\ * Correspondence: mfairuzy@ukm.edu.my
}

check for updates

Citation: Muhammad Abdul Kadar, N.N.; Ahmad, F.; Teoh, S.L.; Yahaya, M.F. Caffeic Acid on Metabolic Syndrome: A Review. Molecules 2021, 26, 5490. https://doi.org/10.3390/ molecules 26185490

Academic Editors: Stefano Castellani and Massimo Conese

Received: 20 August 2021

Accepted: 6 September 2021

Published: 9 September 2021

Publisher's Note: MDPI stays neutral with regard to jurisdictional claims in published maps and institutional affiliations.

Copyright: (c) 2021 by the authors. Licensee MDPI, Basel, Switzerland. This article is an open access article distributed under the terms and conditions of the Creative Commons Attribution (CC BY) license (https:/ / creativecommons.org/licenses/by/ $4.0 /)$.

\begin{abstract}
Metabolic syndrome (MetS) is a constellation of risk factors that may lead to a more sinister disease. Raised blood pressure, dyslipidemia in the form of elevated triglycerides and lowered highdensity lipoprotein cholesterol, raised fasting glucose, and central obesity are the risk factors that could lead to full-blown diabetes, heart disease, and many others. With increasing sedentary lifestyles, coupled with the current COVID-19 pandemic, the numbers of people affected with MetS will be expected to grow in the coming years. While keeping these factors checked with the polypharmacy available currently, there is no single strategy that can halt or minimize the effect of MetS to patients. This opens the door for a more natural way of controlling the disease. Caffeic acid (CA) is a phytonutrient belonging to the flavonoids that can be found in abundance in plants, fruits, and vegetables. CA possesses a wide range of beneficial properties from antioxidant, immunomodulatory, antimicrobial, neuroprotective, antianxiolytic, antiproliferative, and anti-inflammatory activities. This review discusses the current discovery of the effect of CA against MetS.
\end{abstract}

Keywords: caffeic acid; metabolic syndrome; phenolic compound; obesity; dyslipidemia; hyperglycemia; hypertension

\section{Introduction}

Metabolic syndrome (MetS) has affected almost one fifth of the adult population and increases the risk of cardiovascular disease, type-2 diabetes, and all-cause mortality compared to a healthy person [1]. In Asia, Malaysia is recognized as one of the countries that has a high MetS prevalence [2]. MetS is a complication of the modern lifestyle that includes overeating and underactivity [3]. With the current COVID-19 pandemic situation and increasing state of sedentary lifestyle, the numbers are bound to be more than the expected figures in the coming years [4].

The current definition of MetS still uses the Harmonized Criteria that state that abnormal findings of 3 out of 5 of the following risk factors would qualify a person of having MetS: raised blood pressure, dyslipidemia (raised triglycerides (TG) and lowered high-density lipoprotein cholesterol), raised fasting glucose, and central obesity [5,6]. These components have the ability to precede into cardiac dysfunction, but together, they can also cause an additional risk to morbidity and mortality [7]. Although MetS has been collectively accepted as an alarming condition, the clinical world has yet to mutually agree on a uniform terminology and diagnostic criteria. This is mainly due to the adversity of genetic predisposition, diet history, and physical, geographical, and endocrinal attributes that together take part in forming this intricate syndrome [8]. One of the causes of MetS is the increase in oxidative stress and chronic inflammation. In many instances, it has been shown that an antioxidant imbalance may play a role in its development where there is an overproduction of reactive oxygen species (ROS) and nitrogen (RNS) species that can react 
with virtually all biomolecules, causing oxidative damage $[9,10]$. Similarly, human studies have also shown that MetS is associated with oxidative stress and a proinflammatory state that comes with a high antioxidant defense in the peripheral blood mononuclear cells assumed to be derived from a pre-activation state of human cells [11].

Although obesity and insulin resistance remain at the root of MetS pathogenesis, other factors such as chronic stress and dysregulation of the hypothalamic-pituitary-adrenal axis and autonomic nervous system, increased cellular oxidative stress, renin-angiotensinaldosterone activity, and intrinsic tissue glucocorticoid reaction, as well as the newly discovered miRNAs, have been identified to play roles in this condition [12,13].

At the core of many pathological diseases, including MetS, an increase in ROS has played a crucial element that can be tipped over with the aid of a longstanding diet comprising antioxidants [14]. Reactive species are essential signaling molecules that are involved in nearly every physiological activity, from cell division to metabolic regulation. They modulate the activity of biomolecules, and redox-sensitive transcription factors activate a cell's adaptive endogenous response, including antioxidant defense. The degree of reactive species production and neutralization that are tightly associated with oxidative metabolism determines the redox homeostasis of cells and their surroundings. Setting the redox states of cells is critical in both health and disorders such as MetS [15]. The question is, which antioxidant and at what aliquot would be the optimum elixir to shorten the period in combating the specific diseases.

The research world has, for many years, focused on a more natural approach toward combatting human diseases. Synthetic medications have slowly proven its downside over years of pharmacological use. Polypharmacy in the treatment of MetS has become a substantial healthcare burden due to adverse drug reactions, morbidity, and cost [16]. One of the phytonutrient compounds that caught the attention of researchers were the flavonoids. These are a very diverse group of polyphenolic compounds that consists of a benzo- $\gamma$-pyrone and can be found in several parts of a plant. They are classified as plant secondary metabolites having a polyphenolic structure $[17,18]$. These compounds, which can be found in abundance in the Mediterranean diet, has increasingly shown a beneficial effect in maintaining cardiometabolic and cardiovascular health, which, in turn, reduces the risks of MetS development. This positive impression may be due to the diets that are high in polyphenolic antioxidant content derived from vegetables, grapes, and olive oils [19]. Similarly, treatment with naringin, a type of glycoside flavonoid, has been reported to reverse MetS by reducing visceral obesity, blood glucose, blood pressure, and lipid profile [20].

In this review, we discuss a phenolic compound found in many herbs, caffeic acid (CA), or its chemical name 3,4-dihydroxycinnamic acid, which belongs to a group called phenolic compounds, which are a naturally occurring chemical structure found abundantly in fruits and vegetables [21,22].

\section{Caffeic Acid as a Phenolic Compound}

Phenolic compounds provide protection against noncommunicable diseases not only by their means of antioxidant activity but also by regulating a variety of cellular processes at different levels, including enzyme inhibition, modification of gene expression, and protein phosphorylation [23]. An increase in phenolic compounds can alter their health benefits [24]. There are over 8000 phenolic compounds that can be classified into two main groups: flavonoids and nonflavonoids. Flavonoids contain a phenyl benzopyran skeleton: two phenyl rings joined through a heterocyclic pyran ring. Nonflavonoids, on the other hand, are mostly smaller and simpler in comparison to flavonoids [17].

Phenolic acids (PAs) are a group of nonflavonoid phenolic compounds that contain a single phenyl group substituted by a carboxylic group and one or more hydroxyl $(\mathrm{OH})$ groups [25]. PAs are further divided according to the length of the chain that contains the carboxylic group into: hydroxybenzoic acids, hydroxycinnamic acids, and hydroxyphenyl acids. The group hydroxycinnamic acid has a C6-C3 (phenylpropanoid) basic skeleton. 
Hydroxy derivatives of cinnamic acid are more effective as an antioxidant than the hydroxyl derivatives of benzoic acid as the presence of a $\mathrm{CH}_{2}=\mathrm{CH}-\mathrm{COOH}$ group in the cinnamic acids ensures a greater antioxidant capacity than the $\mathrm{COOH}$ group in benzoic acid (Figure 1). One of the major hydroxycinnamic acids is CA [26-28].
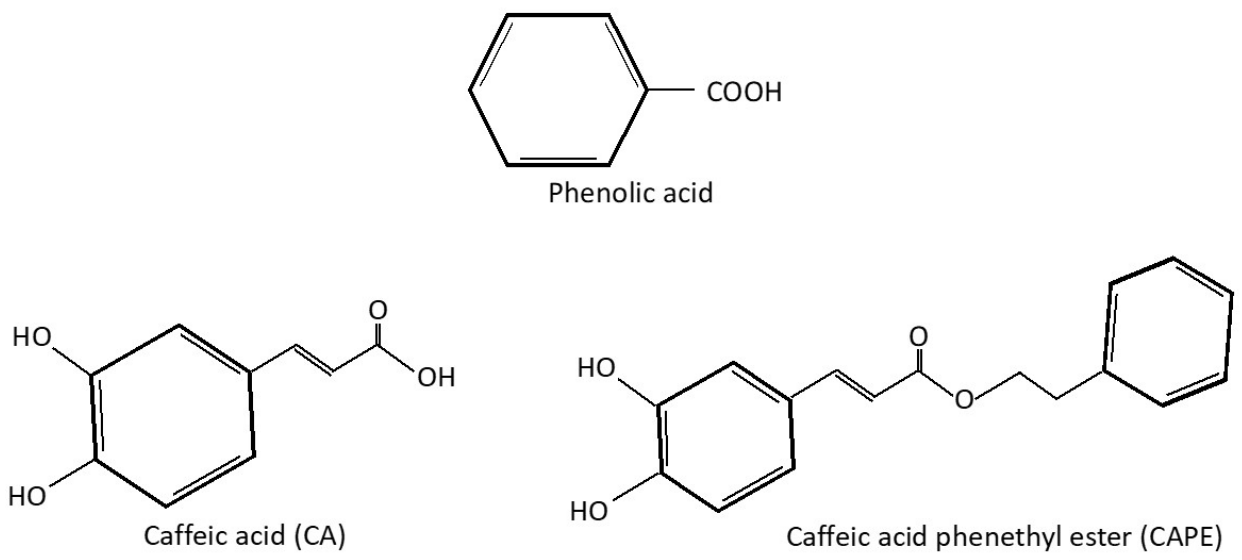

Figure 1. Chemical structure of PA, CA, and CAPE.

CA is found in coffee, honey, potatoes, berries, herbs, and vegetables such as olives, Swiss chard, and carrot [29]. In vitro and in vivo studies have shown that CA not only possesses antioxidant capacity but also has immunomodulatory [30], antimicrobial [31], neuroprotective, antianxiolytic [32], antiproliferative, and anti-inflammatory activities [33], and has shown to improve inflammation and oxidative stress in chronic metabolic diseases. Besides the therapeutic potentials of CA, studies have also shown that the pure form of CA has the availability to be absorbed in the intestines and form subsequent interactions with the target tissue [34]. This solidifies the potential of using CA as an oral route of administration as an appealing choice for a phytonutrient.

CA has also been found in Gelam honey and stingless bee honey through HPLC analysis $[35,36]$. The antioxidant capability of CA is due to its ability to scavenge ROS, including $\mathrm{O}_{2}-, \mathrm{OH}-$, and $\mathrm{H}_{2} \mathrm{O}_{2}$ [37]. CA has shown to be an effective ABTS, DPPH, and superoxide anion radical scavenger, with a total reducing power and metal chelates on ferrous ion activities, in comparison to other standard antioxidant compounds such as BHA, BHT, alpha-tocopherol, and trolox in different in vitro antioxidant assays [38]. Multiple factors influence PA efficacy in vivo, including the amount of consumed chemical, whether it is absorbed or metabolized, its plasma or tissue concentrations, PA type and dosage, and synergistic effects [39].

Besides pure CA, its derivatives in the form of caffeic acid phenyl ester (CAPE) and caffeic acid phenylethyl amide (CAPA) have also been found to have a therapeutic effect against MetS. However, CAPA and CAPE are less stable in its form compared to CA [40]. $\mathrm{CAPE}$ is an active component of the propolis substance and has been known for its antiinflammatory, antioxidant, and anti-cancer effects [41]. The following section discusses the effects of CA and its derivatives on different components of MetS.

\section{CA vs. Obesity}

Obesity is a condition where excess body fat accumulates either due to the enlargement of lipids in existing adipocytes (hypertrophy), or through an increase in the number of adipocytes (hyperplasia) [42]. Adipose tissue in the human body functions as an energy storage system, an endocrine gland, and a heat productor (nonshivering thermogenesis) [43]. In healthy slender individuals, adipocytes are smaller, more insulin-sensitive, and secretes anti-inflammatory mediators such as adiponectin, IL-10, IL-4, IL-13, IL-1 receptor agonist (IL-1Ra), apelin, and transforming growth factor beta (TGF $\beta$ ). In contrast, the adipocytes of an obese individual are enlarged and infiltrated by a large number of 
pro-inflammatory M1 macrophages that secrete pro-inflammatory cytokines such as TNF $\alpha$, IL-6, visfatin, leptin, MCP-1, Ang-II, and plasminogen activator inhibitor-1 [44]. With the surplus of these pro-inflammatory compounds within the obese adipocyte, they are often referred to be in a state of inflammation. This state of chronic low-grade activation of the innate immune system is critical in the pathophysiology of obesity and MetS [45].

Visceral fat is localized within the abdomen and is metabolically active with the constant release of free fatty acids into the portal circulation [46]. In a state of caloric excess, the hypertrophied adipocytes will secrete adipokines that result in the increment of additional pre-adipocytes that will later mature. However, this compensatory act reaches its threshold and causes fat accumulation in the visceral depots. The accumulation and distribution of the fat depots play a key role in forming metabolic complications. A metabolically healthy obese individual that remains insulin-sensitive and displays a normal metabolic and hormonal profile and is physically different compares to a metabolically unhealthy obese person through their higher abdominal circumference measurement [47].

Metabolic changes in obesity are associated with a persistent low-grade inflammatory state that impairs energy homeostasis and glucose metabolism [44,48]. The c-Jun $\mathrm{N}$-terminal kinase (JNK) and the nuclear factor-kappa B (NF-kB) signaling pathways contribute to inflammation and play a key role in obesity, insulin-resistance, and in regulating the expression of proinflammatory molecules [49]. Zhang and colleagues found that CA was able to exert anti-inflammatory effects in dextran sulfate sodium-induced colitis mice, showing a significantly suppressed secretion of IL-6 and TNF $\alpha$ and colonic infiltration of CD3+ T cells, CD177+ neutrophils, and F4/80+ macrophages through the activation of the NF- $\mathrm{kB}$ signaling pathway. Their study concluded that CA was able to amend the colonic pathology and inflammation, indirectly contributing toward reducing obesity [50].

Obesity may also be associated with adipocyte necrosis, which could be the start of a pro-inflammatory response. Adipocytes grow hypertrophic when their caloric intake and energy expenditure increase, which has been linked to cell hypoxia and death. These hypertrophic adipocytes will subsequently start secreting TNF $\alpha$ in small amounts, resulting in a chemotactic response that draws macrophages [48]. An in vitro study using adipose stem cells (ASCs) showed that CAPE had the ability to inverse the effects of high glucose and lipopolysaccharide exposure. Through this study, they found that CAPE treatment was able to restore the functions of adipocytes by increasing the adiponectin and peroxisome proliferator-activated receptor gamma (PPAR $\gamma)$, resulting in the reduction in pro-inflammatory factors [51]. CA also acts on adipogenesis by reducing intracellular lipid accumulation in an in vitro model [52].

Increasing evidence has shown that gut microbiota plays a role in the development of obesity and MetS through the modulation of energy absorption, and subsequently influences glucose and lipid metabolism [53,54]. It was recently postulated that gut microbiota producing t10,c12-conjugated linoleic acid induced lipogenesis [8]. Dietary polyphenols have been found to promote the growth of beneficial bacteria while inhibiting pathogenic bacteria [55]. In an in vivo study to determine the anti-obesity effect of CA, high-fat-diet (HFD)-induced mice were seen to have a positive effect after being given a daily dose of $50 \mathrm{mg} / \mathrm{kg}$ CA for a span of 12 weeks. The researchers noted a significant reduction in body weight and fat accumulation, increases in energy expenditure and beneficial gut bacteria (i.e., Muribaculaceae), and a decrease in pathogenic bacteriae (i.e., Lachnospiraceae) [56].

In another study, HFDs in nonalcoholic fatty liver disease (NAFLD)-induced mice were used to demonstrate the effectiveness of CA treatment and its effects toward the gut microbiota. CA was able to significantly reduce the body weight of the HFD-fed mice and attenuated the expression of lipogenesis-related protein expression (Srebp1, Fas, Acc, and Scd1) in the liver. It was concluded that CA exerted protective effects on the NAFLD mice by inhibiting gut dysbiosis, pro-inflammatory LPS release, and subsequent lipid synthesis [57]. 


\section{CA vs. Hyperglycemia and Insulin Resistance}

One of the primary causes of metabolic and endocrine abnormalities, as well as cellular damage in afflicted tissue, is hyperglycemia-related oxidative stress [15]. Nutrientinduced toxicity due to overnutrition may lead to insulin-resistance in tissues such as the heart and the skeletal muscle, which normally responds to insulin for glucose uptake [58]. Insulin resistance is a condition where the tissues use their adaptive mechanism to avoid toxic nutrient overload [59]. Over time, insulin resistance will cause an increase in fasting glucose and reduced insulin-mediated glucose clearance. Eventually, hyperinsulinemia will occur as a negative feedback from the target cells, signaling inadequate insulin response, and, in turn, the pancreatic $\beta$-cells will produce more insulin. The prolonged inability to correct the state of insulin resistance will eventually give rise to hyperglycemia and type 2 diabetes [60].

CA is found to increase insulin sensitivity through the reduction in proinflammatory cytokines and increase in adiponectins under the hyperglycemic state [51]. In a study that used MetS diet-induced rats, where it caused increases in BMI and abdominal circumference, blood glucose, triglycerides, and LDLc, and lowered the HDLc, the group that received a dose of $40 \mathrm{mg} / \mathrm{kg}$ oral gavage of CA daily for 6 weeks showcased a significant reduction in serum leptin, adiponectin, insulin, TNF-a, IL-6, and IL-8. The study showed that CA had the highest superoxide dismutase (SOD), catalase, and glutathione peroxidase antioxidant enzymes in the liver after 4 weeks of CA administration in comparison to ferulic acid, gallic acid, and protocatechuic acid under the same doses [61]. This suggests that the scavenging activity as a result of CA administration shows the most promising effectivity amongst the listed phenolic acids that protect against hyperglycemic damages.

Nasry et al. investigated the role of pioglitazone (a synthetic PPAR $\gamma$ agonist that causes a decrease in insulin resistance) on HFD-induced-MetS rats, and CA was able to show promising results. There was a significant reduction in insulin resistance, fasting blood glucose, and fasting serum insulin with an increase of insulin sensitivity and $\beta$ cell function. CA also reduces the nitric oxide (NO) liver contents to almost half of those of the HFD-induced MetS rats [62]. This shows the efficacy of CA as scavenging activity toward correcting the insulin resistance through the reduction in oxidative stress caused by the HFD.

CA also suppresses the hepatic glucose output by enhancing its utilization and inhibiting overproduction [63]. This can be seen by the increase in glucokinase activity through an increase in its mRNA expression and glycogen content. It was also found to simultaneously lower the G6Pase and phosphoenolpyruvate carboxykinase activities together with their respective mRNA expressions, along with a decline in the GLUT2 expression in the liver [63].

CA methyl and ethyl esters exert antidiabetic activities in insulin-responsive cells through insulin-independent mechanisms involving AMPK and adipogenic factors [64]. A 2-week treatment of CAPA toward streptozotocin and diet-induced diabetic mice were able to protect them against hepatic inflammation and glucose intolerance associated with the NF-kB-mediated induction of inflammatory cytokines and the increase in the expression of antioxidant protein. HepG2 cell models were then used to further investigate CAPA's ability. They were able to show that CAPA was able to ameliorate TNF $\alpha$-induced $\mathrm{pIKK} \alpha / \beta$ expression and prevent TG accumulation in $\mathrm{H}_{2} \mathrm{O}_{2}$-treated HepG2 cells [40]. These findings strengthen the belief that chronic oral administration of CAPA is able to protect against MetS.

Stress-induced inflammation may cause the development of insulin resistance [65-67]. Stress activates the hypothalamic-pituitary-adrenal axis, renin-angiotensin system pathway, and sympathoadrenal system, all of which are involved in the production of proinflammatory cytokines, resulting in the negative downregulation of insulin signaling by either phosphorylating insulin resistance serine residues or inhibiting Akt, resulting in insulin resistance. CA given to chronic restraint stress-induced insulin-resistance mice 
showed to reduce fasting blood sugar, systemic inflammation, and oxidative stress, and improve insulin sensitivity [68].

\section{CA vs. Dyslipidemia}

Dyslipidemia is described as an abnormal level of circulating lipids. It has been acknowledged that dyslipidaemia increases the risk of cardiovascular disease development [69]. This condition may be of primary cause (genetic) or secondary (diet, drugs, chronic diseases, and metabolic disorders, including MetS). Dyslipidemia is detected through a biochemical analysis of fasting lipid profile, which consists of TG, total cholesterol (TC), high-density lipoprotein cholesterol (HDL-c), low-density lipoprotein cholesterol (LDL-c), and non-HDL-c. Dyslipidemia is diagnosed when there is an increased concentration of TG, TC, LDL-c, and non-HDL-c, along with a decreased level of HDL-c [70].

Free fatty acids (FFA) are abundantly released in an obese body due to the increase in the adipose tissue mass. FFA causes an increase in the synthesis of glucose and TG in the liver, as well as an increase in VLDL secretion. This occurs together with the reduction in HDL-C and increased density of LDL [71]. CA has shown improvement in the serum lipid profile, serum liver biomarker enzymes, and hepatic tissue architecture to normal in HFDinduced hyperlipidemic rat models by showing antihyperlipidemic and hepatoprotective activities. CA was found able to reduce the levels of endoplasmic reticulum stress markers in the liver after a HFD obese induction [72]. Besides CA's ability to revert dyslipidemia by reducing TG and TC, studies have shown that CA was able to revert hepatic steatosis in the long run [49,73-75]. In a recent in vivo study, a 12 week CA supplementation on HFD obese mice revealed that CA was able to reduce body weight and fat accumulation together with readings of improved lipid profile with an increased HDL [56]. This suggests that CA's ability to impair the formation of bad white fat tissue could subsequently reduce FFA production, thereby showing its hepatoprotective ability.

CA is capable of providing a TG-lowering, anticoagulatory, antioxidative, and antiinflammatory protection for the cardiac tissue and also downregulating the TNF- $\alpha$ and monocyte chemoattractant protein- 1 mRNA expression in the kidney of diet-induced diabetic rats [76]. Studies on diet-induced hypercholesterolemic rats by Agunloye and Oboh compared the modulatory properties of CA and chlorogenic acid, proving that CA was a better candidate in ameliorating the pathological condition. They also tested two different dosages of the drug (10 mg/ $\mathrm{kg}$ and $15 \mathrm{mg} / \mathrm{kg}$ of CA) and concluded the lipid-lowering effects were more effective at larger doses [77].

It is possible that an excessive amount of oxidative stress and/or inflammation can convert circulating LDL and HDL particles into oxidized LDL (oxLDL) and oxidized HDL particles (oxHDL). OxLDL and oxHDL both stay longer in the bloodstream due to their impaired interaction with their specific receptors. Their diminished clearance and imbalance of lipid profile ultimately contributes to the onset of atherosclerosis [19]. CA is thought to prevent atherosclerosis by lowering the functional and structural changes in the arteries [78]. This has been demonstrated by its ability to inhibit thrombogenic thromboxane A2 (TXA2) production together with other platelet-aggregating molecules [79,80]. CA also downregulated platelet-activating molecules such as COX-1, calcium ions, and P-selectin and upregulated platelet-inhibiting molecules such as cAMP and cGMP, resulting in an inhibition toward thrombogenic processes [81].

\section{CA vs. Hypertension}

Almost $80 \%$ of the individuals with MetS suffer from hypertension. Evidence concurred that $65-75 \%$ of the risk factor for primary hypertension is contributed by obesity and excess weight gain [82]. Besides, insulin resistance has also been linked to hypertension as insulin is able to cross the blood-brain barrier and subsequently activate the systemic nervous system, in addition to its ability to upregulate the angiotensin II (AT-II) receptor and reduce $\mathrm{NO}$ [60]. NO is one of the most important ROS in the cardiovascular 
system. ROS are produced by NO synthase enzymatically, and they act as a prototype endothelial-derived vasodilator [83].

$\mathrm{N} \omega$-Nitro-L-arginine-methyl ester (L-NAME) is a well-known active inhibitor of NO production in the nerves and the endothelial cell. A study using L-NAME-induced hypertensive rats showed that a combination of caffeine and $\mathrm{CA}$ was able to reduce the systolic BP. A decrease in ACE and arginase activity coupled with high NO and low MDA levels might be associated with their antihypertensive effects $[84,85]$. In another study using CAPE against the high-fructose corn syrup diet-induced vascular damage in rats, blood pressure values were significantly reduced after a two-week intraperitoneal injection with CA derivative. This study also noted that CAPE has the ability to correct the reduced levels of endothelial NO synthase levels caused by the high-fructose corn syrup diet [73].

According to a more recent study, CA has a favorable effect on the vascular function and blood pressure stabilization. In this study, male SERCA2a knockout mice and its wild-type were surgically implanted with mini osmotic pumps filled with AT-II solutions and fed with a normal diet of $0.05 \% \mathrm{CA}$ in drinking water. CA significantly attenuated the AT-II-induced increase in blood pressure reading in the wildtype mice but showed no hypotensive effect to the SERCA2a knockout mice. This suggests that the CA might act by activating the SERCA2a on the primary vascular smooth muscle cells [86].

CA has also been reported to be a potent antihypertensive agent and has been confirmed to have a nontoxic manifestation $[87,88]$. Agunloye and Oboh's in vitro study revealed that $\mathrm{CA}$ was capable of inhibiting key enzymes associated with hypertension that includes E-NTPDase, $5^{\prime}$-ectonucleotidase, ADA, ACE, arginase, and AChE. This study suggested that CA targets specific enzymes associated with hypertension [89]. Decreased ACE and arginase activity, as well as high NO and low MDA levels, might be associated with their antihypertensive effects [77]. The summary for MetS studies related to CA can be found in Table 1, whereas the proposed pathway for CA against MetS can be found in Figure 2 .

Table 1. MetS studies related to CA.

\begin{tabular}{|c|c|c|c|c|}
\hline Pathological Induction/State & $\begin{array}{c}\text { Dose of CA or Its } \\
\text { Derivates and } \\
\text { Administration Route }\end{array}$ & $\begin{array}{l}\text { Duration of } \\
\text { Treatment }\end{array}$ & Observations & Reference \\
\hline $\begin{array}{l}\text { Diet-induced MetS with HFD } \\
\text { in male Wistar rats }\end{array}$ & $40 \mathrm{mg} / \mathrm{kg}$ via oral gavage & 6 weeks & $\begin{array}{l}\text { Reduced: } \\
\text {-Insulin } \\
\text {-HOMA-IR } \\
\text {-Leptin } \\
\text {-TNF } \alpha \\
\text {-IL-6 } \\
\text {-IL-8 } \\
\text {-Total cholesterol, TG,VLDLc, } \\
\text { LDLc,HDLc } \\
\text { Increased: } \\
\text {-Adiponectin }\end{array}$ & [61] \\
\hline $\begin{array}{l}\text { Diet-induced hypercholesterolemic } \\
\text { rats }\end{array}$ & 10 and $15 \mathrm{mg} / \mathrm{kg}$ & 21 days & $\begin{array}{l}\text { Reduced: } \\
\quad \text { —Total cholesterol } \\
\text { —-TG } \\
\quad \text { —LDL } \\
\text { — HDL } \\
\text { (With dose } 15 \mathrm{mg} / \mathrm{kg} \text { showing better } \\
\text { results) } \\
\text { Increased: } \\
\quad \text { —Plasma and heart SOD } \\
\text { activity }\end{array}$ & [77] \\
\hline $\begin{array}{l}\mathrm{N} \omega \text {-Nitro-L-argininge- } \\
\text { methylester (L-NAME)-induced } \\
\text { hypertensive in male Wistar rats }\end{array}$ & $\begin{array}{c}5 \mathrm{mg} / \mathrm{kg} \text { and } 25 \mathrm{mg} / \mathrm{kg} \text { via } \\
\text { oral gavage }\end{array}$ & 20 days & $\begin{array}{l}\text { Reduced: } \\
\text { —SBP } \\
\text { —-MDA } \\
\text { Increased: } \\
\text { —ACE activity } \\
\text { - NOx level }\end{array}$ & [85] \\
\hline
\end{tabular}


Table 1. Cont.

\begin{tabular}{|c|c|c|c|c|}
\hline Pathological Induction/State & $\begin{array}{c}\text { Dose of CA or Its } \\
\text { Derivates and } \\
\text { Administration Route }\end{array}$ & $\begin{array}{c}\text { Duration of } \\
\text { Treatment }\end{array}$ & Observations & Reference \\
\hline $\begin{array}{l}\text { Surgically implanted mini osmotic } \\
\text { pumps filled with } \\
\text { Ang II solution in wild type } \\
\text { mice and SERCA2a knockout mice }\end{array}$ & $0.05 \%$ CA in drinking water & 8 weeks & $\begin{array}{l}\text { CA was able to: } \\
\text { —-Relax mesenteric artery } \\
\text { —-Smooth norepinephrine-induced } \\
\text { vasoconstriction } \\
\text { —-Reduced intracellular } \mathrm{Ca}^{2+} \text { ions } \\
\text { —-Bind to SERCA forming strong } \\
\text { hydrogen bonds } \\
\text {-Significantly attenuated } \\
\text { AngII-induced hypertension. } \\
\text { However, CA failed to do so in } \\
\text { SERCA2a knockout mice }\end{array}$ & [86] \\
\hline $\begin{array}{l}\text { HFD obesity-induced } \\
\text { C57BL/6J mice }\end{array}$ & $50 \mathrm{mg} / \mathrm{kg}$ via oral gavage & 12 weeks & Reduced serum insulin & [56] \\
\hline $\begin{array}{l}\text { Alloxan-induced type-1 diabetic in } \\
\text { Swiss albino mice }\end{array}$ & $\begin{array}{l}50 \mathrm{mg} / \mathrm{kg} \text { intraperitoneal } \\
\text { injection }\end{array}$ & 7 days & $\begin{array}{l}\text { Protective effects on liver and kidneys } \\
\text { Hypoglycemic and hypolipidemic } \\
\text { properties. }\end{array}$ & [75] \\
\hline $\begin{array}{l}\text { STZ-induced diabetic male Wistar } \\
\text { rats }\end{array}$ & $\begin{array}{l}10 \text { and } 50 \mathrm{mg} / \mathrm{kg} \text { via oral } \\
\text { gavage (diluted in canola oil) }\end{array}$ & 30 days & $\begin{array}{l}\text { Reduced } \\
\text { —FBS } \\
\text { —oxidative stress parameters (lipid } \\
\text { peroxidation, reactive species } \\
\text { production, protein oxidation, and } \\
\text { MPO activity). }\end{array}$ & [90] \\
\hline STZ-induced diabetic rats & orally & 5 weeks & $\begin{array}{l}\text { Increased: } \\
\quad \text { — serum insulin level } \\
\quad \text { —GSH, CAT, and SOD levels } \\
\text { Reduced: } \\
\quad \text { - Blood glucose level } \\
\text { Histologically seen normal islet } \\
\text { morphology in CA administered diabetic } \\
\text { rats. }\end{array}$ & [91] \\
\hline $\begin{array}{l}\text { STZ and high-fat } \\
\text { high-fructose-diet-induced CD1 } \\
\text { (ICR) mice }\end{array}$ & $10 \mathrm{mg} / \mathrm{kg} /$ day of CAPA orally & 2 weeks & $\begin{array}{l}\text { Reduced } \\
\text { —-Body weight increase } \\
\text { —Plasma retinol binding protein } 4 \\
\text { (RBP4) } \\
\text { —Adiponectin level } \\
\text {-TNF } \alpha \text { in liver } \\
\text { Preserved glucose tolerance } \\
\text { Prevented glucose intolerance } \\
\text { Preserved basal coronary flow }\end{array}$ & [40] \\
\hline $\begin{array}{c}\text { Insulin-resistant adipocytes } \\
\text { ASCs exposed to high glucose } \\
\text { levels }\end{array}$ & & & $\begin{array}{l}\text { Decreased lipid droplets and radical } \\
\text { oxygen species formation. } \\
\text { Increased insulin sensitivity (showed } \\
\text { reduction in pro-inflammatory cytokines } \\
\text { level and increased adiponectins). }\end{array}$ & [51] \\
\hline $\begin{array}{l}\text { HFD inducing NAFLD in } \\
\text { C57BL/6J mice }\end{array}$ & $\begin{array}{c}0.08 \% \text { or } 0.16 \% \text { CA added to } \\
\text { pellet diet }\end{array}$ & 8 weeks & $\begin{array}{l}\text { Reduced body weight in both } \\
\text { concentrations. } \\
\text { Positively altered the community } \\
\text { compositional structure of gut } \\
\text { microbiota. }\end{array}$ & [57] \\
\hline
\end{tabular}


Table 1. Cont.

\begin{tabular}{|c|c|c|c|c|}
\hline Pathological Induction/State & $\begin{array}{c}\text { Dose of CA or Its } \\
\text { Derivates and } \\
\text { Administration Route }\end{array}$ & $\begin{array}{l}\text { Duration of } \\
\text { Treatment }\end{array}$ & Observations & Reference \\
\hline $\begin{array}{c}\text { Non-insulin-dependent DM } \\
\text { (NIDDM) and insulin-resistant (IR) } \\
\text { mice models }\end{array}$ & $\begin{array}{c}15 \text { and } 30 \mathrm{mg} / \mathrm{kg} \text { CAPE } \\
\text { dissolved in PEG-400 given } \\
\text { via oral gavage. }\end{array}$ & 5 weeks & $\begin{array}{l}\text { Improved: } \\
\text { —-Insulin sensitivity } \\
\text { - Hyperlipidemia } \\
\text { —-Peroxisome-proliferator- } \\
\text { activated receptor- } \alpha \text { (PPAR- } \alpha \text { ) } \\
\text { —TNF } \alpha \\
\text { —Glucose consumption } \\
\text { —Glucose uptake } \\
\text { —-Glycogen content } \\
\text { —Oxidative stress level } \\
\text {-Decreased level of } \\
\text { glucose-6-phosphotase expression } \\
\text { (G6Pase). }\end{array}$ & [49] \\
\hline HFD-induced obesity in mice & $50 \mathrm{mg} / \mathrm{kg} /$ day orally & 10 weeks & $\begin{array}{l}\text { Reduced: } \\
\text { —-Body weight } \\
\text { - Liver weight } \\
\text { - Liver lipid accumulation } \\
\text { - Levels of ER stress markers in } \\
\text { the liver } \\
\text { Improved glucose intolerance and } \\
\text { insulin sensitivity. }\end{array}$ & [72] \\
\hline $\begin{array}{l}\text { High fructose corn syrup- } \\
\text { induced vascular dysfunction } \\
\text { in Sprague Dawley rats }\end{array}$ & $\begin{array}{c}50 \mathrm{mmol} / \mathrm{kg} \text { intraperitoneal } \\
\text { injection }\end{array}$ & 2 weeks & $\begin{array}{l}\text { Reduced SBP } \\
\text { Increased NO synthase production. } \\
\text { Significant reduction in TC and LDL. } \\
\text { No significant change to HDL nor TG. }\end{array}$ & [73] \\
\hline $\begin{array}{l}\text { Chronic restraint stress-induced } \\
\text { insulin resistance in LACA mice }\end{array}$ & $\begin{array}{l}5 \text { and } 10 \mathrm{mg} / \mathrm{kg} \\
\text { intraperitoneal injections }\end{array}$ & 30 days & $\begin{array}{l}\text { Reduces: } \\
\text { —Fasting blood sugar } \\
\text { —-Systemic inflammation } \\
\text { —-Oxidative stress } \\
\text { - Improved insulin sensitivity }\end{array}$ & [68] \\
\hline HFD-induced MetS in C57 mice & $\begin{array}{c}\text { A combination of ferulic acid } \\
(50 \mathrm{mg} / \mathrm{kg} / \text { day) with CA } 0.9 \\
\mathrm{mg} / \mathrm{kg} / \text { day via subcutaneous } \\
\text { injection }\end{array}$ & 40 days & $\begin{array}{l}\text { Prevents obesity. } \\
\text { Reverts hyperglycemia. } \\
\text { Reverts dyslipidemia. } \\
\text { Reverts hepatic steatosis. }\end{array}$ & [74] \\
\hline $\begin{array}{l}\text { High-fat-diet and STZ-induced } \\
\text { diabetic male Wistar rats }\end{array}$ & $40 \mathrm{mg} / \mathrm{kg}$ via oral gavage & 8 weeks & $\begin{array}{l}\text { Improved albumin excretion by kidneys. } \\
\text { Improved blood glucose } \\
\text { Reduced renal mesangial matrix } \\
\text { extension. } \\
\text { CA results were seen better in reversing } \\
\text { the diabetic nephropathy in comparison } \\
\text { to prevention. }\end{array}$ & [92] \\
\hline $\begin{array}{l}\text { L-NAME-induced Sprague } \\
\text { Dawley rats }\end{array}$ & $\begin{array}{l}50 \mu \mathrm{mol} / \mathrm{kg} / \text { day } \\
\text { intraperitoneally }\end{array}$ & 14 days & $\begin{array}{l}\text { Kidney tissue analysis shows that CA } \\
\text { was: } \\
\text {-Unable to preserve PON1 activity } \\
\text {-Unable to reduce NF- } \mathrm{BB} \\
\text { significantly }\end{array}$ & [93] \\
\hline Hyperlipidemic Wistar Albino & $20 \mathrm{mg} / \mathrm{kg} /$ day & 30 days & $\begin{array}{l}\text { Significantly reduced: } \\
\text { - Total cholesterol } \\
\text {-TG } \\
\text { - HDL-c }\end{array}$ & [94] \\
\hline
\end{tabular}




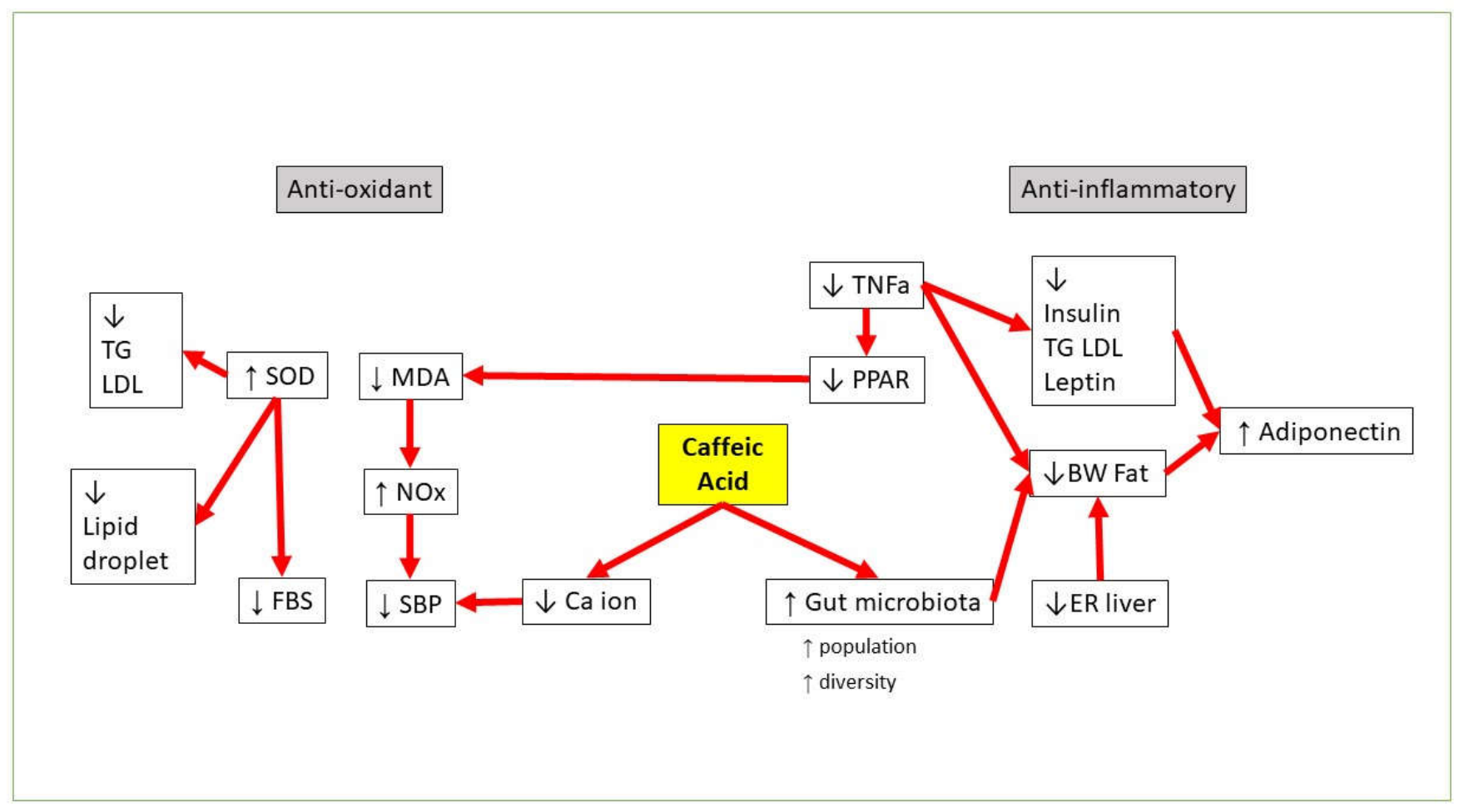

Figure 2. Proposed CA pathways against MetS.

\section{Conclusions}

There has been enormous progress in understanding the effect of CA through retrospective research. Strong evidence of the ability of CA to reverse the MetS effects through the reduction in inflammatory markers such as TNF $\alpha$ coupled with reduced oxidative stress parameters have guided researchers to a more proteomic and metabolomic approach Besides the singular usage of CA, studies of using CA as an enhancer together with more commonly used drugs have surfaced. Through this review, we can conclude that CA holds strong potential to be used as MetS management by its anti-obesity, antidiabetic, hypolipidemic, and hypotensive activities. During the course of drafting this manuscript, we identified a substantial gap in which the wealth of knowledge about CA is limited to findings in animal models or cell lines. Further studies in the form of a clinical trial or a population cohort study would further strengthen the beneficial effect of CA on MetS.

Author Contributions: Conceptualization, N.N.M.A.K. and M.F.Y.; writing-original draft preparation, N.N.M.A.K.; writing-review and editing, M.F.Y., F.A. and S.L.T.; supervision, M.F.Y., F.A. and S.L.T.; project administration, M.F.Y.; funding acquisition, M.F.Y. All authors have read and agreed to the published version of the manuscript.

Funding: This research was funded by PPUKM Fundamental Grant, grant number FF-2019-014.

Conflicts of Interest: The authors declare no conflict of interest.

\section{References}

1. Ranasinghe, P.; Mathangasinghe, Y.; Jayawardena, R.; Hills, A.; Misra, A. Prevalence and trends of metabolic syndrome among adults in the asia-pacific region: A systematic review. BMC Public Health 2017, 17, 107. [CrossRef]

2. Manaf, M.R.A.; Nawi, A.M.; Tauhid, N.M.; Othman, H.; Rahman, M.R.A.; Yusoff, H.M.; Safian, N.; Ng, P.Y.; Manaf, Z.A.; Kadir, N.B.A.; et al. Prevalence of metabolic syndrome and its associated risk factors among staffs in a Malaysian public university. Sci. Rep. 2021, 11, 1-11. [CrossRef]

3. Ando, K.; Fujita, T. Metabolic syndrome and oxidative stress. Free Radic. Biol. Med. 2009, 47, 213-218. [CrossRef]

4. Martinez-Ferran, M.; De La Guía-Galipienso, F.; Sanchis-Gomar, F.; Pareja-Galeano, H. Metabolic Impacts of Confinement during the COVID-19 Pandemic due to Modified Diet and Physical Activity Habits. Nutrients 2020, 12, 1549. [CrossRef] 
5. $\quad$ Alberti, K.G.M.M.; Eckel, R.H.; Grundy, S.M.; Zimmet, P.; Cleeman, J.I.; Donato, K.A.; Fruchart, J.-C.; James, W.P.T.; Loria, C.M.; Smith, S.C., Jr. Harmonizing the Metabolic Syndrome. Circulation 2009, 120, 1640-1645. [CrossRef]

6. EEckel, R.H.; Alberti, K.G.M.M.; Grundy, S.M.; Zimmet, P.Z. The metabolic syndrome. Lancet 2010, 375, 181-183. [CrossRef]

7. Li, A.; Zheng, N.; Ding, X. Mitochondrial abnormalities: A hub in metabolic syndrome-related cardiac dysfunction caused by oxidative stress. Heart Fail. Rev. 2021, 1-8. [CrossRef]

8. Etchegoyen, M.; Nobile, M.H.; Baez, F.; Posesorski, B.; González, J.; Lago, N.; Milei, J.; Otero-Losada, M. Metabolic Syndrome and Neuroprotection. Front. Neurosci. 2018, 12, 196. [CrossRef]

9. Li, S.; Tan, H.-Y.; Wang, N.; Zhang, Z.-J.; Lao, L.; Wong, C.-W.; Feng, Y. The Role of Oxidative Stress and Antioxidants in Liver Diseases. Int. J. Mol. Sci. 2015, 16, 26087-26124. [CrossRef] [PubMed]

10. Maritim, A.C.; Sanders, R.A.; Watkins, J.B. Diabetes, oxidative stress, and antioxidants: A review. J. Biochem. Mol. Toxicol. 2003, 17, 24-38. [CrossRef]

11. Monserrat-Mesquida, M.; Quetglas-Llabrés, M.; Capó, X.; Bouzas, C.; Mateos, D.; Pons, A.; Tur, J.A.; Sureda, A. Metabolic Syndrome Is Associated with Oxidative Stress and Proinflammatory State. Antioxidants 2020, 9, 236. [CrossRef] [PubMed]

12. Hanson, R.L.; Imperatore, G.; Bennett, P.H.; Knowler, W.C. Components of the "metabolic syndrome" and incidence of type 2 diabetes. Diabetes 2002, 51, 3120-3127. [CrossRef]

13. Kassi, E.; Pervanidou, P.; Kaltsas, G.; Chrousos, G. Metabolic syndrome: Definitions and controversies. BMC Med. 2011, 9, 48. [CrossRef] [PubMed]

14. Sies, H.; Jones, D.P. Reactive oxygen species (ROS) as pleiotropic physiological signalling agents. Nat. Rev. Mol. Cell Biol. 2020, 21, 363-383. [CrossRef] [PubMed]

15. Korac, B.; Kalezic, A.; Pekovic-Vaughan, V.; Korac, A.; Jankovic, A. Redox changes in obesity, metabolic syndrome, and diabetes. Redox Biol. 2021, 42, 101887. [CrossRef]

16. Quinn, K.J.; Shah, N.H. A dataset quantifying polypharmacy in the United States. Sci. Data 2017, 4, 170167. [CrossRef] [PubMed]

17. Kumar, S.; Pandey, A.K. Chemistry and Biological Activities of Flavonoids: An Overview. Sci. World J. 2013, 2013, e162750. [CrossRef] [PubMed]

18. Panche, A.N.; Diwan, A.D.; Chandra, S.R. Flavonoids: An overview. J. Nutr. Sci. 2016, 5, e47. [CrossRef]

19. Feldman, F.; Koudoufio, M.; Desjardins, Y.; Spahis, S.; Delvin, E.; Levy, E. Efficacy of Polyphenols in the Management of Dyslipidemia: A Focus on Clinical Studies. Nutrients 2021, 13, 672. [CrossRef]

20. Kumar, S.R.; Ramli, E.S.M.; Nasir, N.A.A.; Ismail, N.H.M.; Fahami, N.A.M. Preventive Effect of Naringin on Metabolic Syndrome and Its Mechanism of Action: A Systematic Review. Altern. Med. 2019, 2019, e9752826. [CrossRef]

21. Azuma, K.; Ippoushi, K.; Nakayama, M.; Ito, H.; Higashio, H.; Terao, J. Absorption of chlorogenic acid and caffeic acid in rats after oral administration. J. Agric. Food Chem. 2000, 48, 5496-5500. [CrossRef] [PubMed]

22. Manish, P.; Wei Ling, L.; Seong Lin, T.; Mohamad Fairuz, Y. Flavonoids and its Neuroprotective Effects on Brain Ischemia and Neurodegenerative Diseases. Curr. Drug Targets 2018, 19, 1710-1720. [CrossRef]

23. Kasprzak-Drozd, K.; Oniszczuk, T.; Stasiak, M.; Oniszczuk, A. Beneficial Effects of Phenolic Compounds on Gut Microbiota and Metabolic Syndrome. Int. J. Mol. Sci. 2021, 22, 3715. [CrossRef] [PubMed]

24. Saibabu, V.; Fatima, Z.; Khan, L.A.; Hameed, S. Therapeutic Potential of Dietary Phenolic Acids. Adv. Pharmacol. Sci. 2015, 2015, 823539. [CrossRef] [PubMed]

25. Leonard, W.; Zhang, P.; Ying, D.; Fang, Z. Hydroxycinnamic acids on gut microbiota and health. Compr. Rev. Food Sci. Food Saf. 2021, 20, 710-737. [CrossRef]

26. Göçer, H.; Gülçin, I. Caffeic acid phenethyl ester (CAPE): Correlation of structure and antioxidant properties. Int. J. Food Sci. Nutr. 2011, 62, 821-825. [CrossRef] [PubMed]

27. Filipe, H.; Sousa, C.; Marquês, J.T.; Vila-Viçosa, D.; de Granada-Flor, A.; Viana, A.; Santos, M.; Machuqueiro, M.; de Almeida, R.F. Differential targeting of membrane lipid domains by caffeic acid and its ester derivatives. Free Radic. Biol. Med. 2018, 115, 232-245. [CrossRef]

28. Vinayagam, R.; Jayachandran, M.; Xu, B. Antidiabetic Effects of Simple Phenolic Acids: A Comprehensive Review. Phytother. Res. 2016, 30, 184-199. [CrossRef]

29. Armutcu, F.; Akyol, S.; Ustunsoy, S.; Turan, F.F. Therapeutic potential of caffeic acid phenethyl ester and its anti-inflammatory and immunomodulatory effects (Review). Exp. Ther. Med. 2015, 9, 1582-1588. [CrossRef] [PubMed]

30. KKępa, M.; Miklasińska-Majdanik, M.; Wojtyczka, R.D.; Idzik, D.; Korzeniowski, K.; Smoleń-Dzirba, J.; Wąsik, T.J. Antimicrobial Potential of Caffeic Acid against Staphylococcus aureus Clinical Strains. BioMed Res. Int. 2018, 2018, e7413504. [CrossRef]

31. Kim, Y.H.; Sung, Y.-H.; Lee, H.-H.; Ko, I.-G.; Kim, S.-E.; Shin, M.-S.; Kim, B.-K. Postnatal treadmill exercise alleviates short-term memory impairment by enhancing cell proliferation and suppressing apoptosis in the hippocampus of rat pups born to diabetic rats. J. Exerc. Rehabil. 2014, 10, 209-217. [CrossRef]

32. Koga, M.; Nakagawa, S.; Kato, A.; Kusumi, I. Caffeic acid reduces oxidative stress and microglial activation in the mouse hippocampus. Tissue Cell 2019, 60, 14-20. [CrossRef]

33. Pereira, P.; De Oliveira, P.A.; Ardenghi, P.; Rotta, L.; Henriques, J.A.P.; Picada, J.N. Neuropharmacological analysis of caffeic acid in rats. Basic Clin. Pharmacol. Toxicol. 2006, 99, 374-378. [CrossRef]

34. Sato, Y.; Itagaki, S.; Kurokawa, T.; Ogura, J.; Kobayashi, M.; Hirano, T.; Sugawara, M.; Iseki, K. In vitro and in vivo antioxidant properties of chlorogenic acid and caffeic acid. Int. J. Pharm. 2011, 403, 136-138. [CrossRef] [PubMed] 
35. Kassim, M.; Achoui, M.; Mustafa, M.R.; Mohd, M.A.; Yusoff, K.M. Ellagic acid, phenolic acids, and flavonoids in Malaysian honey extracts demonstrate in vitro anti-inflammatory activity. Nutr. Res. 2010, 30, 650-659. [CrossRef]

36. Ramli, N.Z.; Chin, K.-Y.; Zarkasi, K.A.; Ahmad, F. The Beneficial Effects of Stingless Bee Honey from Heterotrigona itama against Metabolic Changes in Rats Fed with High-Carbohydrate and High-Fat Diet. Environ. Res. Public Health 2019, 16, 4987. [CrossRef] [PubMed]

37. Kolgazi, M.; Cilingir, S.; Yilmaz, O.; Gemici, M.; Yazar, H.; Ozer, S.; Acikel-Elmas, M.; Arbak, S.; Suyen, G.G. Caffeic acid attenuates gastric mucosal damage induced by ethanol in rats via nitric oxide modulation. Chem.-Biol. Interact. 2021, 334, 109351. [CrossRef]

38. Gülçin, İ. Antioxidant activity of caffeic acid (3,4-dihydroxycinnamic acid). Toxicology 2006, 217, 213-220. [CrossRef] [PubMed]

39. Piazzon, A.; Vrhovsek, U.; Masuero, D.; Mattivi, F.; Mandoj, F.; Nardini, M. Antioxidant activity of phenolic acids and their metabolites: Synthesis and antioxidant properties of the sulfate derivatives of ferulic and caffeic acids and of the acyl glucuronide of ferulic acid. J. Agric. Food Chem. 2012, 60, 12312-12323. [CrossRef] [PubMed]

40. Weng, Y.-C.; Chuang, S.-T.; Lin, Y.-C.; Chuang, C.-F.; Chi, T.-C.; Chiu, H.-L.; Kuo, Y.-H.; Su, M.-J. Caffeic Acid Phenylethyl Amide Protects against the Metabolic Consequences in Diabetes Mellitus Induced by Diet and Streptozocin. Evid.-Based Complement. Altern. Med. 2012, 2012, e984780. [CrossRef]

41. Shin, E.J.; Jo, S.; Choi, H.-K.; Choi, S.; Byun, S.; Lim, T.-G. Caffeic Acid Phenethyl Ester Inhibits UV-Induced MMP-1 Expression by Targeting Histone Acetyltransferases in Human Skin. Int. J. Mol. Sci. 2019, 20, 3055. [CrossRef]

42. Honecker, J.; Weidlich, D.; Heisz, S.; Lindgren, C.M.; Karampinos, D.C.; Claussnitzer, M.; Hauner, H. A distribution-centered approach for analyzing human adipocyte size estimates and their association with obesity-related traits and mitochondrial function. Int. J. Obes. 2021, 45, 2108-2117. [CrossRef] [PubMed]

43. Cannon, B.; Nedergaard, J. Brown adipose tissue: Function and physiological significance. Physiol. Rev. 2004, 84, 277-359. [CrossRef]

44. Jayarathne, S.; Koboziev, I.; Park, O.-H.; Oldewage-Theron, W.; Shen, C.-L.; Moustaid-Moussa, N. Anti-Inflammatory and Anti-Obesity Properties of Food Bioactive Components: Effects on Adipose Tissue. Prev. Nutr. Food Sci. 2017, 22, 251-262. [CrossRef] [PubMed]

45. Engin, A.B. Adipocyte-Macrophage Cross-Talk in Obesity. In Obesity and Lipotoxicity; Engin, A.B., Engin, A., Eds.; Springer International Publishing: Cham, Switzerland, 2017; pp. 327-343. [CrossRef]

46. Jensen, M.D. Visceral Fat: Culprit or Canary? Endocrinol. Metab. Clin. N. Am. 2020, 49, 229-237. [CrossRef] [PubMed]

47. Chait, A.; den Hartigh, L.J. Adipose Tissue Distribution, Inflammation and Its Metabolic Consequences, Including Diabetes and Cardiovascular Disease. Front. Cardiovasc. Med. 2020, 7, 22. [CrossRef] [PubMed]

48. Parekh, P.J.; Arusi, E.; Vinik, A.I.; Johnson, D.A. The Role and Influence of Gut Microbiota in Pathogenesis and Management of Obesity and Metabolic Syndrome. Front. Endocrinol. 2014, 5, 47. [CrossRef]

49. Nie, J.; Chang, Y.; Li, Y.; Zhou, Y.; Qin, J.; Sun, Z.; Li, H. Caffeic Acid Phenethyl Ester (Propolis Extract) Ameliorates Insulin Resistance by Inhibiting JNK and NF-kB Inflammatory Pathways in Diabetic Mice and HepG2 Cell Models. J. Agric. Food Chem. 2017, 65, 9041-9053. [CrossRef]

50. Zhang, Z.; Wu, X.; Cao, S.; Wang, L.; Wang, D.; Yang, H.; Feng, Y.; Wang, S.; Shoulin, W. Caffeic acid ameliorates colitis in association with increased Akkermansia population in the gut microbiota of mice. Oncotarget 2016, 7, 31790-31799. [CrossRef]

51. Vanella, L.; Tibullo, D.; Godos, J.; Pluchinotta, F.R.; Di Giacomo, C.; Sorrenti, V.; Acquaviva, R.; Russo, A.; Volti, G.L.; Barbagallo, I. Caffeic Acid Phenethyl Ester Regulates PPAR's Levels in Stem Cells-Derived Adipocytes. PPAR Res. 2016, 2016 , e7359521. [CrossRef] [PubMed]

52. Mariana, B.D.; Tiago, L.S.; Ramon, R.P.P.B.D.M.; Jamile, M.F.; Tiago, S.M.; Richard, R.C.M.; Hector, G.R.; Dânya, B.L.; Alice, M.C.M.; Maria, G.R.D.Q. Caffeic acid reduces lipid accumulation and reactive oxygen species production in adipocytes. Afr. J. Pharm. Pharmacol. 2018, 12, 263-268. [CrossRef]

53. Boulangé, C.L.; Neves, A.L.; Chilloux, J.; Nicholson, J.K.; Dumas, M.-E. Impact of the gut microbiota on inflammation, obesity, and metabolic disease. Genome Med. 2016, 8, 42. [CrossRef]

54. Ridaura, V.K.; Faith, J.J.; Rey, F.E.; Cheng, J.; Duncan, A.E.; Kau, A.; Griffin, N.W.; Lombard, V.; Henrissat, B.; Bain, J.R.; et al. Gut Microbiota from Twins Discordant for Obesity Modulate Metabolism in Mice. Science 2013, 341, 1241214. [CrossRef]

55. Dueñas, M.; Muñoz-Gonzalez, I.; Cueva, C.; Jiménez-Girón, A.; Sánchez-Patán, F.; Santos-Buelga, C.; Moreno-Arribas, M.; Bartolomé, B. A Survey of Modulation of Gut Microbiota by Dietary Polyphenols. BioMed Res. Int. 2015, 2015, e850902. [CrossRef] [PubMed]

56. Xu, J.; Ge, J.; He, X.; Sheng, Y.; Zheng, S.; Zhang, C.; Xu, W.; Huang, K. Caffeic acid reduces body weight by regulating gut microbiota in diet-induced-obese mice. J. Funct. Foods 2020, 74, 104061. [CrossRef]

57. Mu, H.-N.; Zhou, Q.; Yang, R.-Y.; Tang, W.-Q.; Li, H.-X.; Wang, S.-M.; Li, J.; Chen, W.-X.; Dong, J. Caffeic acid prevents nonalcoholic fatty liver disease induced by a high-fat diet through gut microbiota modulation in mice. Food Res. Int. 2021, 143, 110240. [CrossRef]

58. Freeman, A.M.; Pennings, N. Insulin Resistance. In StatPearls; StatPearls Publishing: Treasure Island, FL, USA, 2021. Available online: http:/ / www.ncbi.nlm.nih.gov/books/NBK507839/ (accessed on 12 August 2021).

59. Nolan, C.J.; Ruderman, N.B.; Kahn, S.E.; Pedersen, O.; Prentki, M. Insulin Resistance as a Physiological Defense Against Metabolic Stress: Implications for the Management of Subsets of Type 2 Diabetes. Diabetes 2015, 64, 673-686. [CrossRef] 
60. Hashim, K.-N.; Chin, K.-Y.; Ahmad, F. The Mechanism of Honey in Reversing Metabolic Syndrome. Molecules 2021, $26,808$. [CrossRef]

61. Ibitoye, O.B.; Ajiboye, T.O. Dietary phenolic acids reverse insulin resistance, hyperglycaemia, dyslipidaemia, inflammation and oxidative stress in high-fructose diet-induced metabolic syndrome rats. Arch. Physiol. Biochem. 2018, 124, 410-417. [CrossRef]

62. Nasry, M.R.; Abo-Youssef, A.M.; Zaki, H.F.; El-Denshary, E.-E.-D.S. Effect of caffeic acid and pioglitazone in an experimental model of metabolic syndrome. Int. J.Sci. Res. Publ. 2015, 5, 1-9.

63. JJung, U.J.; Lee, M.-K.; Park, Y.B.; Jeon, S.-M.; Choi, M.-S. Antihyperglycemic and Antioxidant Properties of Caffeic Acid in db/db Mice. J. Pharmacol. Exp. Ther. 2006, 318, 476-483. [CrossRef]

64. Eid, H.M.; Thong, F.; Nachar, A.; Haddad, P.S. Caffeic acid methyl and ethyl esters exert potential antidiabetic effects on glucose and lipid metabolism in cultured murine insulin-sensitive cells through mechanisms implicating activation of AMPK. Pharm. Biol. 2017, 55, 2026-2034. [CrossRef] [PubMed]

65. Feng, Y.; Feng, Q.; Qu, H.; Song, X.; Hu, J.; Xu, X.; Zhang, L.; Yin, S. Stress adaptation is associated with insulin resistance in women with gestational diabetes mellitus. Nutr. Diabetes 2020, 10, 4. [CrossRef] [PubMed]

66. Jimenez, V.; Sanchez, N.; Clark, E.L.M.; Miller, R.L.; Casamassima, M.; Verros, M.; Conte, I.; Ruiz-Jaquez, M.; Gulley, L.D.; Johnson, S.A.; et al. Associations of adverse childhood experiences with stress physiology and insulin resistance in adolescents at risk for adult obesity. Dev. Psychobiol. 2021, 63, 1-10. [CrossRef] [PubMed]

67. Poplawski, J.; Radmilovic, A.; Montina, T.D.; Metz, G.A.S. Cardiorenal metabolic biomarkers link early life stress to risk of non-communicable diseases and adverse mental health outcomes. Sci. Rep. 2020, 10, 13295. [CrossRef]

68. Choudhary, S.; Mourya, A.; Ahuja, S.; Sah, S.P.; Kumar, A. Plausible anti-inflammatory mechanism of resveratrol and caffeic acid against chronic stress-induced insulin resistance in mice. Inflammopharmacology 2016, 24, 347-361. [CrossRef]

69. Gonna, H.; Ray, K.K. The importance of dyslipidaemia in the pathogenesis of cardiovascular disease in people with diabetes. Diabetes Obes. Metab. 2019, 21, 6-16. [CrossRef]

70. Pappan, N.; Rehman, A. Dyslipidemia. In StatPearls; StatPearls Publishing: Treasure Island, FL, USA, 2021. Available online: http:/ / www.ncbi.nlm.nih.gov / books/NBK560891/ (accessed on 12 August 2021).

71. Cornier, M.-A.; Dabelea, D.; Hernandez, T.L.; Lindstrom, R.C.; Steig, A.J.; Stob, N.R.; Van Pelt, R.E.; Wang, H.; Eckel, R.H. The Metabolic Syndrome. Endocr. Rev. 2008, 29, 777-822. [CrossRef] [PubMed]

72. Kim, H.; Kim, Y.; Lee, E.S.; Huh, J.H.; Chung, C.H. Caffeic acid ameliorates hepatic steatosis and reduces ER stress in high fat diet-induced obese mice by regulating autophagy. Nutrition 2018, 55-56, 63-70. [CrossRef] [PubMed]

73. Gun, A.; Ozer, M.K.; Bilgiç, S.; Kocaman, N.; Ozan, G. Effect of Caffeic Acid Phenethyl Ester on Vascular Damage Caused by Consumption of High Fructose Corn Syrup in Rats. Oxidative Med. Cell. Longev. 2016, 2016, e3419479. [CrossRef] [PubMed]

74. Bocco, B.M.L.D.C.; Fernandes, G.W.; Lorena, F.; Cysneiros, R.; Christoffolete, M.; Grecco, S.; Lancellotti, C.; Romoff, P.; Lago, J.H.G.; Bianco, A.; et al. Combined treatment with caffeic and ferulic acid from Baccharis uncinella C. DC. (Asteraceae) protects against metabolic syndrome in mice. Braz. J. Med Biol. Res. 2016, 49, e5003. [CrossRef] [PubMed]

75. Oršolić, N.; Sirovina, D.; Odeh, D.; Gajski, G.; Balta, V.; Šver, L.; Jembrek, M.J. Efficacy of Caffeic Acid on Diabetes and Its Complications in the Mouse. Molecules 2021, 26, 3262. [CrossRef]

76. Chao, C.-Y.; Mong, M.-C.; Chan, K.-C.; Yin, M.-C. Anti-glycative and anti-inflammatory effects of caffeic acid and ellagic acid in kidney of diabetic mice. Mol. Nutr. Food Res. 2010, 54, 388-395. [CrossRef]

77. Agunloye, O.M.; Oboh, G. Hypercholesterolemia, angiotensin converting enzyme and ecto-enzymes of purinergic system: Ameliorative properties of caffeic and chlorogenic acid in hypercholesterolemic rats. J. Food Biochem. 2018, 42, e12604. [CrossRef]

78. Hassan, N.A.; El-Bassossy, H.M.; Mahmoud, M.; Fahmy, A. Caffeic acid phenethyl ester, a 5-lipoxygenase enzyme inhibitor, alleviates diabetic atherosclerotic manifestations: Effect on vascular reactivity and stiffness. Chem.-Biol. Interact. 2014, $213,28-36$. [CrossRef] [PubMed]

79. Lee, D.-H.; Kim, H.-H.; Cho, H.-J.; Bae, J.-S.; Yu, Y.-B.; Park, H.-J. Antiplatelet effects of caffeic acid due to Ca ${ }^{2+}$ mobilizationinhibition via cAMP-dependent inositol-1, 4, 5-trisphosphate receptor phosphorylation. J. Atheroscler. Thromb. 2014, $21,23-37$. [CrossRef]

80. Lu, Y.; Li, Q.; Liu, Y.-Y.; Sun, K.; Fan, J.-Y.; Wang, C.-S.; Han, J.-Y. Inhibitory effect of caffeic acid on ADP-induced thrombus formation and platelet activation involves mitogen-activated protein kinases. Sci. Rep. 2015, 5, 13824. [CrossRef]

81. Nam, G.S.; Nam, K.-S.; Park, H.-J. Caffeic Acid Diminishes the Production and Release of Thrombogenic Molecules in Human Platelets. Biotechnol. Bioprocess Eng. 2018, 23, 641-648. [CrossRef]

82. Mendoza, M.F.; Kachur, S.M.; Lavie, C.J. Hypertension in obesity. Curr. Opin. Cardiol. 2020, 35, 389-396. [CrossRef]

83. Touyz, R.M.; Rios, F.J.; Alves-Lopes, R.; Neves, K.B.; Camargo, L.D.L.; Montezano, A.C. Oxidative Stress: A Unifying Paradigm in Hypertension. Can. J. Cardiol. 2020, 36, 659-670. [CrossRef]

84. Surikow, S.; Nguyen, T.; Stafford, I.; Horowitz, J. Inhibition of Nitric Oxide Synthase: Impact on Cardiovascular Injury and Mortality in a Model of Takotsubo Syndrome. Heart Lung Circ. 2019, 28, S132. [CrossRef]

85. Oboh, G.; Ojueromi, O.O.; Ademosun, A.O.; Omayone, T.P.; Oyagbemi, A.A.; Ajibade, T.O.; Adedapo, A.A. Effects of caffeine and caffeic acid on selected biochemical parameters in L-NAME-induced hypertensive rats. J. Food Biochem. 2021, $45,13384$. [CrossRef] [PubMed]

86. Wu, H.; Zhang, L.; Gao, P.; Liu, D.; Zhu, Z. Caffeic Acid Ameliorates Angiotensin II-induced Increase In Blood Pressure by Activating Vascular Sarco-/Endoplasmic Reticulum CA-ATPASE2A. J. Hypertens. 2021, 39, e248. [CrossRef] 
87. Li, P.-G.; Xu, J.-W.; Ikeda, K.; Kobayakawa, A.; Kayano, Y.; Mitani, T.; Ikami, T.; Yamori, Y. Caffeic Acid Inhibits Vascular Smooth Muscle Cell Proliferation Induced by Angiotensin II in Stroke-Prone Spontaneously Hypertensive Rats. Hypertens. Res. 2005, 28, 369-377. [CrossRef]

88. Bhullar, K.S.; Lassalle-Claux, G.; Touaibia, M.; Rupasinghe, H.V. Antihypertensive effect of caffeic acid and its analogs through dual renin-angiotensin-aldosterone system inhibition. Eur. J. Pharmacol. 2014, 730, 125-132. [CrossRef]

89. Agunloye, O.M.; Oboh, G. Caffeic acid and chlorogenic acid: Evaluation of antioxidant effect and inhibition of key enzymes linked with hypertension. J. Food Biochem. 2018, 42, e12541. [CrossRef]

90. Castro, M.F.V.; Stefanello, N.; Assmann, C.E.; Baldissarelli, J.; Bagatini, M.D.; da Silva, A.D.; da Costa, P.; Borba, L.; da Cruz, I.B.M.; Morsch, V.M.; et al. Modulatory effects of caffeic acid on purinergic and cholinergic systems and oxi-inflammatory parameters of streptozotocin-induced diabetic rats. Life Sci. 2021, 277, 119421. [CrossRef]

91. Xu, W.; Luo, Q.; Wen, X.; Xiao, M.; Mei, Q. Antioxidant and anti-diabetic effects of caffeic acid in a rat model of diabetes. Trop. J. Pharm. Res. 2020, 19, 1227-1232. [CrossRef]

92. Matboli, M.; Eissa, S.; Ibrahim, D.; Hegazy, M.; Imam, S.S.; Habib, E.K. Caffeic Acid Attenuates Diabetic Kidney Disease via Modulation of Autophagy in a High-Fat Diet/Streptozotocin- Induced Diabetic Rat. Sci. Rep. 2017, 7, 2263. [CrossRef]

93. Salmas, R.E.; Gulhan, M.F.; Durdagi, S.; Sahna, E.; Abdullah, H.I.; Selamoglu, Z. Effects of propolis, caffeic acid phenethyl ester, and pollen on renal injury in hypertensive rat: An experimental and theoretical approach. Cell Biochem. Funct. 2017, 35, 304-314. [CrossRef]

94. Taher, M.A.; Hussain, D.A.A.; Hasan, H.F.; Fahmi, Z.M.; Luaibi, O.K.; Ali, M.G. Hypolipidemic Effect of Caffeic Acid Isolated From Arctium Lappa Cultivated In Iraq, in Hyperlipidemic Rat Model. Iraqi J. Pharm. Sci. 2015, 24, 18-24. 